\title{
Consequences of keeping Mytilus in the laboratory as assessed by different cellular condition indices
}

\author{
M. P. Cajaraville, G. Díez, I. A. Marigómez \& E. Angulo \\ Zitologi eta Histologi Laborategia, Biologia Zelularra eta Zientzia Morfologikoen Saila, \\ Zientzi Fakultatea; Euskal Herriko Unibertsitatea, 644 P. K, 48080-Bilbo, Spain
}

\begin{abstract}
Mytilus galloprovincialis Lmk. were maintained in the laboratory for three monthis in a semicontinuous water flow system. Animals were fed a commercial filter-feeder food and sampled after $0,21,35,49,77$, and 91 days. In order to establish whether laboratory conditions and the food used were deleterious to mussels, their health status was assessed by quantifying different histological parameters of the digestive gland tissue. It was concluded that mussels kept for more than 35 days under the described laboratory conditions showed signs of stress presumably caused by the reproductive state of the mussels investigated. The food used and the nutrition-related health status of the animals were adequate, as shown by transmission electron microscopical studies after the 91day maintenance period. A stress response was also evoked by a 10-day starvation period, which was reflected by an increased proportion of type I and type IV digestive tubules, and a reduced "Mean Epithelial Thickness" (MET). Finally, the results demonstrate the sensitivity of quantitative histological diagnosis in comparison to subjective tubule grading procedures in the assessment of the degree of stress experienced by mussels.
\end{abstract}

\section{INTRODUCTION}

Mussels are used world-wide in monitoring programmes as pollution indicators (Goldberg, 1986). Mussels are ideal monitoring species as they are dominant members of coastal and estuarine communities, accumulate different toxicants in their tissues, are responsive to many environmental pollutants, and have a wide geographical distribution (Livingstone et al., 1988). This situation has created an increased interest in keeping mussel populations in the laboratory in order to monitor the effects of pollutants in partially controlled conditions (Bayne \& Thompson, 1970). Livingstone et al. (1988) report that mussels do not display stress due to prolonged handling, while long-term experiments carried out both in laboratory flow-through systems and mesocosm basins indicate the opposite (Bayne \& Thompson, 1970; Bayne, 1973; Lowe, 1988). Non-stressing maintenance protocols for animals of potential biomonitoring use are rare (Sindermann, 1988). Besides, the nutritional status of test animals is a factor that might modify the toxicity of waterborne chemicals to aquatic organisms (Lanno et al., 1989).

Mussels show some physiological requirements that make their maintenance in the laboratory difficult. Microalgae are the major source of food, and thus, mussels are usually maintained in the laboratory on monoalgal diets of different species of microalgae or on mixtures of algae, the latter often resulting in higher growth rates (Hummel, 1985). Furthermore, food has to be provided continuously at a certain concentration for long- 
term experiments. Algal cultures of considerable volume have to be grown for this purpose. These features require time-consuming care and an infrastructure not always available in research laboratories. For these reasons we decided to test an artificial commercial diet for feeding mussels. The present work on the mussel Mytilus galloprovincialis Lmk., maintained under constant conditions of immersion, reports quantitative changes in histology of the digestive gland monitored over a three-month period.

Histological diagnosis at the electron microscope level is a highly sensitive method of detecting early responses to starvation, as demonstrated in the investigations on hepatopancreatic R-cells of crustaceans (Storch et al., 1982; Storch \& Burkhardt, 1984). Several papers have shown that the ingestion of inappropriate food also leads to histopathological changes (Storch \& Burkhardt, 1984; Vogt et al., 1986; Segner et al., 1987) that are distinguishable from changes induced by starvation (Segner et al., 1987). Histological diagnosis at the light and electron microscope level is also of great help in monitoring the effects of pollutants such as pesticides (Vogt, 1987), aromatic hydrocarbons (Robinson \& Dillaman, 1985; Cajaraville et al., 1990b, c) and metals (Papathanassiou \& King, 1986; Marigómez et al., 1990; 1991) in a variety of invertebrates.

As in crustaceans, the digestive gland (or hepatopancreas) of molluscs shows a great natural plasticity, and the morphology of the digestive tubules changes considerably with alterations of environmental conditions (Thompson et al., 1974; Lowe et al., 1981; Couch, 1984; Axiak et al., 1988; Vega et al., 1989). In the present investigation, the digestive tubule structure was measured in terms of mean epithelial thickness, mean diverticular radius and mean luminal radius by using a planimetric procedure (Vega et al., 1989). A subjective tubule grading method was also used to estimate the proportions of tubules at different digestive stages (Langton, 1975; Robinson \& Langton, 1980). The volume density of basophilic cells was determined in paraffin sections by a point-counting method (Cajaraville et al., 1990a). These quantitative parameters can serve as a basis to evaluate the degree of stress in natural and cultivated populations of mussels. Transmission electron microscopy was also used to provide a further analysis of the condition of the digestive and basophilic cells after the three-month maintenance period. The gonad index (Seed, 1969) was determined to assess the reproductive state of mussels.

The objective of the present study was thus twofold: first, to establish whether the laboratory conditions used were themselves deleterious to mussels, and second, to determine the sensitivity of the different histological stress parameters described above in the detection of subtle changes in mussel condition. Special attention was also paid to the assessment of the nutritive value of the food used.

\section{MATERIALS AND METHODS}

\section{Experimental procedure}

Mussels, collected from Meñakoz, Biscay $\left(43^{\circ} 24^{\prime} \mathrm{N}, 2^{\circ} 93^{\prime} \mathrm{W}\right)$ in March 1988 , were transferred to the laboratory. 50 individuals $(2.5-3.5 \mathrm{~cm}$ shell length) were distributed in 25-1 polyethylene covered tanks in a thermostatized semicontinuous water flow system using natural seawater (Zierbena, Biscay) filtered through activated charcoal and glasswool, the water being replaced every 2 days. Mussels were maintained unfed at $15-16^{\circ} \mathrm{C}$ for 10 days to provide acclimatization to laboratory conditions. Thereafter, individuals 
were kept in replicate series for three months under natural photoperiods and fed with a commercial filter-feeder food (Marine Invertebrate Diet, Hawaiian Marine Imports Inc., distributed by Carolina Ltd.). The food was a mixture of selected organic particles and amino acids (ingredients: casein, dried yeast, thiamine, riboflavin, niacin, sodium benzoate, ascorbic acid and sodium chloride). Approximately two drops were added per tank every day. Faeces were mechanically removed from the tanks once a day before the addition of fresh food. The tanks were continuously aerated. Water-temperature was recorded every working day; it averaged $15.25 \pm 1.01^{\circ} \mathrm{C}$ in April, $16.17 \pm 0.77^{\circ} \mathrm{C}$ in May, and $16.47 \pm 1.20^{\circ} \mathrm{C}$ in June.

\section{Planimetric analysis of digestive tubules and tubule grading method}

Mussels were sampled after $0,21,35,49,77$, and 91 days. Five animals were removed from each replicate experimental group at each sampling period, except in the sample 0 (10-day starved animals), where a total of 44 animals was used. After the animals had been removed from the shell, a portion of the mantle-digestive gland tissue was carefully excised and fixed in Bouin's fluid. Following dehydration through an ascending ethanol series, the tissues were cleared in methylbenzoate and embedded in paraffin. Sections $(9 \mu \mathrm{m})$ were cut and stained with haematoxylin-eosin $(\mathrm{H} / \mathrm{E})$. Observations on the presence/absence of the crystalline style were carried out for each animal, and although no attempt was made to measure style length, its size was subjectively graded into small, intermediate and large.

In order to quantify the morphological structure of the digestive tubules, a planimetric procedure (based on the geometrical transformation of a tubule section into a regular geometrical figure) was applied (Recio et al., 1988). Five tubule sections were selected in each of the five fields of two different sections of the digestive gland (45-180 $\mu \mathrm{m}$ from one another). The selection of fields within a given section was made by always starting at the top-right angle of the tissue. Further fields were selected at given intervals across the tissue section, the direction of movement always having the same zig-zag pattern. Thus, 50 tubule sections were drawn per mussel $(50 \times 10=500$ tubule sections per experimental group) with the aid of a drawing-tube attachment to a Nikon "Optiphot" microscope (total magnification $670 \times$ ). When necrotic tubules (see below) were present, only the outer profile of the tubule section could be drawn. In cases where a part of the digestive tubule epithelium still showed structural integrity, both inner and outer profiles of this part of the epithelium were drawn. Section profiles were recorded by means of a Watanabe DT1000 digitizer, and planimetric measures calculated by an Olivetti M240 personal computer following the procedure of Vega et al. (1989). Five parameters were obtained: Mean Epithelial Thickness (MET), Mean Diverticular Radius (MDR), Mean Luminal Radius (MLR), MET/MDR ratio and MLR/MET ratio. The three absolute parameters are calculated as follows: (1) MET = according to Recio et al. (1988); (2) MDR = $\sqrt{\mathrm{Ao} / \pi}$; and (3) MLR $=\sqrt{\mathrm{Ai} / \pi}$; where Ao and Ai are the areas enclosed by the outer and the inner shapes of the tubule section, respectively (Vega et al., 1989).

Besides, the digestive tubules used for the calculation of the planimetric parameters were also analysed using a subjective tubule grading method. The calculation of proportions and variances of each tubule type per animal was based on the classification of 50 tubules. Each tubule was classified according to the following types: holding (type 1), 
absorptive (type II), disintegrating (type III) and reconstituting (type IV) (Langton, 1975; Robinson \& Langton, 1980). A fifth tubule type was considered to be necrotic, as previously described by Cajaraville et al. (1989). Necrotic tubules are characterized by the absence of a well-delimited inner borderline of the tubule section as the lumen of the tubule is completely filled with cell debris and with cells undergoing autolysis. Thus, this tubule type is defined by a MET value close to $0 \mu \mathrm{m}$.

\section{Stereological analysis of basophilic cells}

A stereological procedure was applied in order to quantify the volume density of basophilic cells. Counts were made in each of the five fields of the two different sections of the digestive gland $(45-180 \mu \mathrm{m}$ from one another). The selection of fields within a given section was made as described above for the planimetric analysis of digestive tubules. Thus, cell counts were made in 10 fields per mussel $(10 \times 10=100$ countings per experimental group). A Weibel graticule (multipurpose test system M-168) was used (Weibel, 1979), and hits on basophilic cells and on the remaining digestive tissue were recorded. From these values, the volume density (VD) of basophilic cells was determined using the following equation:

$$
\mathrm{VD}=\frac{\mathrm{X} 1+\mathrm{X} 2+\ldots+\mathrm{Xn}}{\mathrm{m} \times \mathrm{n}}
$$

where: $\mathrm{X}$ : number of segment edges falling on basophilic cells, $\mathrm{m}$ : total number of segment edges falling on digestive tissue, $\mathrm{n}$ : number of counts made ( 10 for each mussel).

\section{Histological studies of gonad development}

The arbitrary scheme of classification of the gonad condition reported by Seed (1969) for Mytilus edulis was used. Four main stages were thus recognized (developing, ripe, spawning and spent), and the mean gonad index for each sample was determined as in Seed (1969). Each sample comprised 10 individuals, except on the first sampling day (0) when 44 animals were graded. The index varies from zero when all individuals in the sample are in the spent condition, to five when all individuals are fully mature.

\section{Transmission electron microscopy}

For electron microscopy, samples of animals were taken after 91 days. Tissue blocks from the digestive gland were fixed in $2.5 \%$ glutaraldehyde in phosphate buffer $(+2.5 \%$ $\mathrm{NaCl})$ at $\mathrm{pH} 7.4$ for $2 \mathrm{~h}$ at $4^{\circ} \mathrm{C}$. The samples were rinsed in phosphate-buffered sucrose $(1: 3$ sucrose $0.38 \mathrm{M})$ and post-fixed in $1 \%$ osmium tetroxide in phosphate buffer at $\mathrm{pH}$ 7.4 for $1 \mathrm{~h}$. After dehydration through an ascending ethanol series into propylene oxide, specimens were embedded in Durcupan resin (ACM Fluka). Blocks were cut on an LKB ultramicrotome. Semithin sections were stained with toluidine blue and examined by light microscopy. Ultrathin sections were collected on copper grids and stained with uranyl acetate and lead citrate. Observations were made in a JEOL (JEM 100 SX) electron microscope at $60 \mathrm{kV}$. 


\section{Statistics}

Fiducial intervals were calculated using Student's $t$-test, and significant differences between means were established at $\mathrm{p}<0.05$ level (Sokal \& Rohlf, 1979). One-way analysis of variance (ANOVA) was used to test significant differences between the sampling periods for each parameter (significance level $\mathrm{p}<0.05$ ). Correlation and regression analyses were carried out to establish significant relationships among the studied parameters. For these analyses the statistical package SPSS/PC+ (SPSS Inc., Microsoft Co.) was used in an AT personal computer (Atlas 286). Linear regression analyses were also performed to test the dependence of changes in GI with time.

\section{RESULTS}

No mortality was recorded in one of the tanks during the whole experiment. However, mussels from the other aquarium started to die by day 65 in a massive fashion, and no animals survived by day 77. This mortality was accompanied by a cloudy appearance of the water at day 65 and was probably due to an accidental overuse of food affecting water quality.

Crystalline styles were rarely lacking in animals sampled at any time through the assay (Fig. 1a). Microscopical observation of the style sac region showed that crystalline styles of different sizes were present in $71 \%, 100 \%, 80 \%, 63 \%, 100 \%$ and $80 \%$ of the animals sampled after $0,21,35,49,77$ and 91 days, respectively. There was no apparent relationship between style size and maintenance conditions.

The total GI showed a continuous decrease over the experimental period (Fig. 2). GI values at the start of the experiment indicated that mussels were already spawning on March 29. Nevertheless, total GI values did not appear to reflect accurately the reproductive condition of the mussels. Consequently, GI was calculated separately for both males and females; and animals that could not be sexed (graded as 0 ) were added in equal shares to males and females. The general trend in female mussels was a lowering of the GI, with a mean GI value of 0 attained at the end of the experiment. A gradual decrease of GI was also observed in male mussels, although GI values of males were consistently higher than those of females. Regression analyses indicated a significant linear relationship between each total GI, female GI and male GI and time (Table 1). The slopes of the three curves were very similar but the $\mathrm{Y}$ intercept value was higher in males than in females. Abnormal conditions, such as hemocytic infiltration of follicles containing mature gametes (Bayne et al., 1978), were very rarely observed (3 cases). Mussels in the spent or resting phase (predominant in the 77- and 91-day samples) always showed follicles empty of gametes and frequently filled with hemocytes and/or brown cells.

Results of the planimetric analysis of the digestive gland tubules are given in Figure 3. The analysis of variance (Table 2) indicates that the five planimetric parameters differ significantly between samples. MET values increased steadily from day 0 to day 35 while values obtained in later samplings were markedly lower (Fig. 3a). Two different groups were also distinguished when MET/MDR values were considered (Fig. 3d). Similarly, mussels sampled until day 35 showed low values of MLR/MET while those sampled later showed high MLR/MET mean values (Fig. 3e). Digestive tubule size (MDR) increased from day 0 to day 35 and showed little further change (Fig. $3 \mathrm{~b}$ ). Digestive tubule lumen 

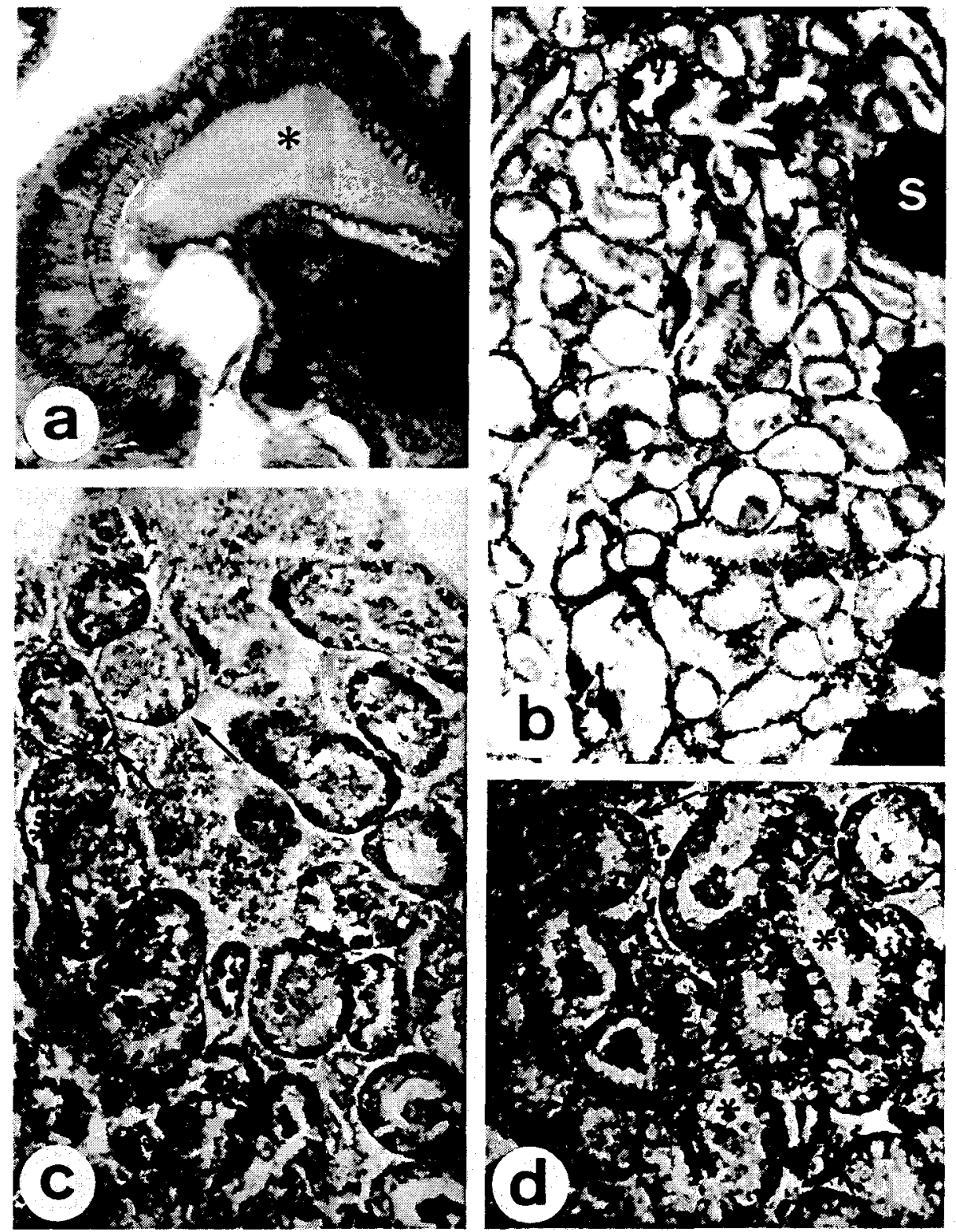

Fig. 1a-d. Mytilus galloprovincialis. Light microscopy; cross-sections through the digestive gland. a: Stomach of a mussel sampled at day 0 , after 10 days starvation, showing the crystalline style (asterisk); $\times 180$. b: Digestive gland tubules of a 10-day starved mussel. Note that most tubules are of the reconstituting type (or type IV). $S=$ sperm; $\times 95$. c: General morphology of necrotic tubules (arrows) in a mussel sampled at day $35, \times 190, \mathrm{~d}$ : Digestive gland tubules of a mussel sampled at day 35. Note that type I tubules (arrows) are relatively small, while type III tubules (asterisks) are relatively large; $\times 180$ 


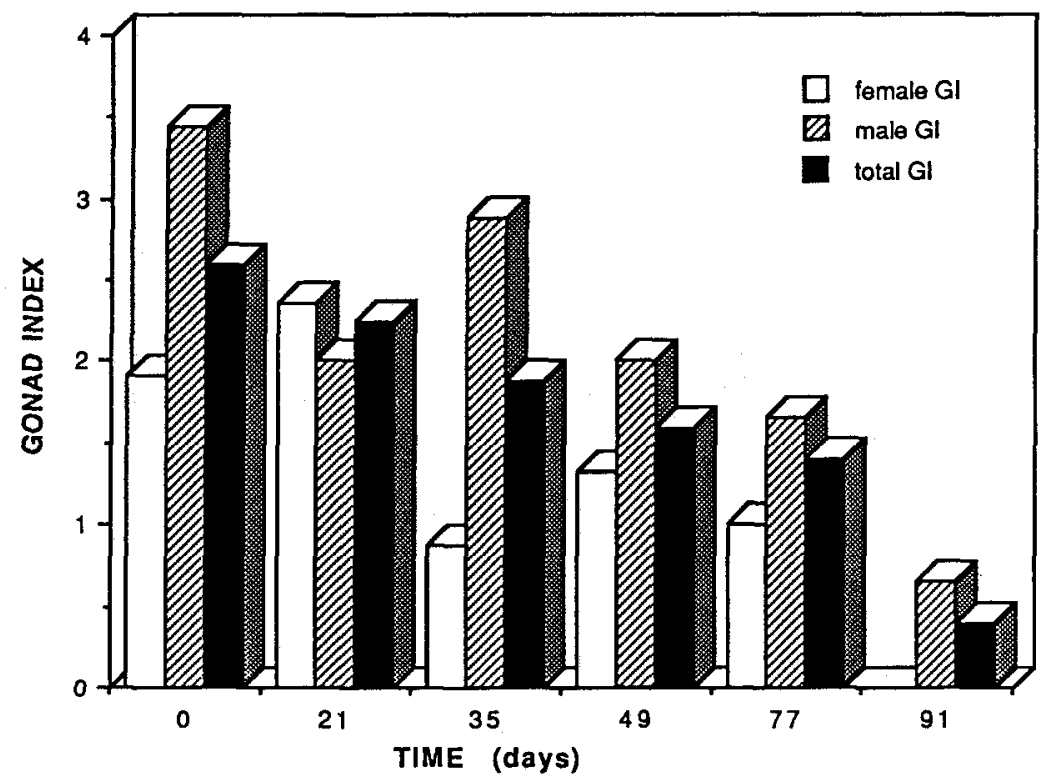

Fig. 2. Values of the Gonad Index (GI) for females, males and for the total experimental population at the sampling periods

size (MLR) also increased over the experimental period (Fig. 3c), maximum values being obtained on days 77 and 91 .

Data concerning changes in the percentages of the different tubule types over the experimental period are shown in Figure 4 and Table 2. The percentage of type I tubules showed some time-related changes, although not statistically significant (Fig. 4a, Table 2), and most of the tubules were at stages II and III on every sampling day. No timedependent coherent trend was observed in the percentages of these two tubule types (Figs $4 \mathrm{~b}$ and $4 \mathrm{c}$ ), although type II tubule percentage was markedly decreased on day 91 correlating with an increased percentage of type III tubules. The percentage of type IV tubules was very low on day 21 and gradually increased through the experimental period (Fig. 4d). The percentage of the latter type of tubule was high in the group of starved mussels (Fig. 1b) where type I tubules were also relatively abundant. Necrotic tubules (Fig. 1c) were always a very low percentage of the total tubule population and their quantity did not change significantly during the assay (Fig. 4e, Table 2).

The results of the stereological analysis of basophilic cells are given in Figure 5 . The basophilic cell volume density (VD) of mussels maintained without food was low and

Table 1. Regression equations of female, male and total Gonad Index (GI) against time; t: time; $r$ : correlation coefficient; $P$ : signification of $r$

$$
\begin{aligned}
& \mathrm{GI}_{\mathrm{f}}=-0.0202 \mathrm{t}+2.1673 ; \quad \mathrm{r}=-0.8321(\mathrm{P}=0.0399) \\
& \mathrm{GI}_{\mathrm{m}}=-0.0250 \mathrm{t}+3.2497 ; \quad \mathrm{r}=-0.8838(\mathrm{P}=0.0195) \\
& \mathrm{GI}_{\mathrm{t}}=-0.0226 \mathrm{t}+2.7085 ; \mathrm{r}=-0.7603(\mathrm{P}=0.0041)
\end{aligned}
$$



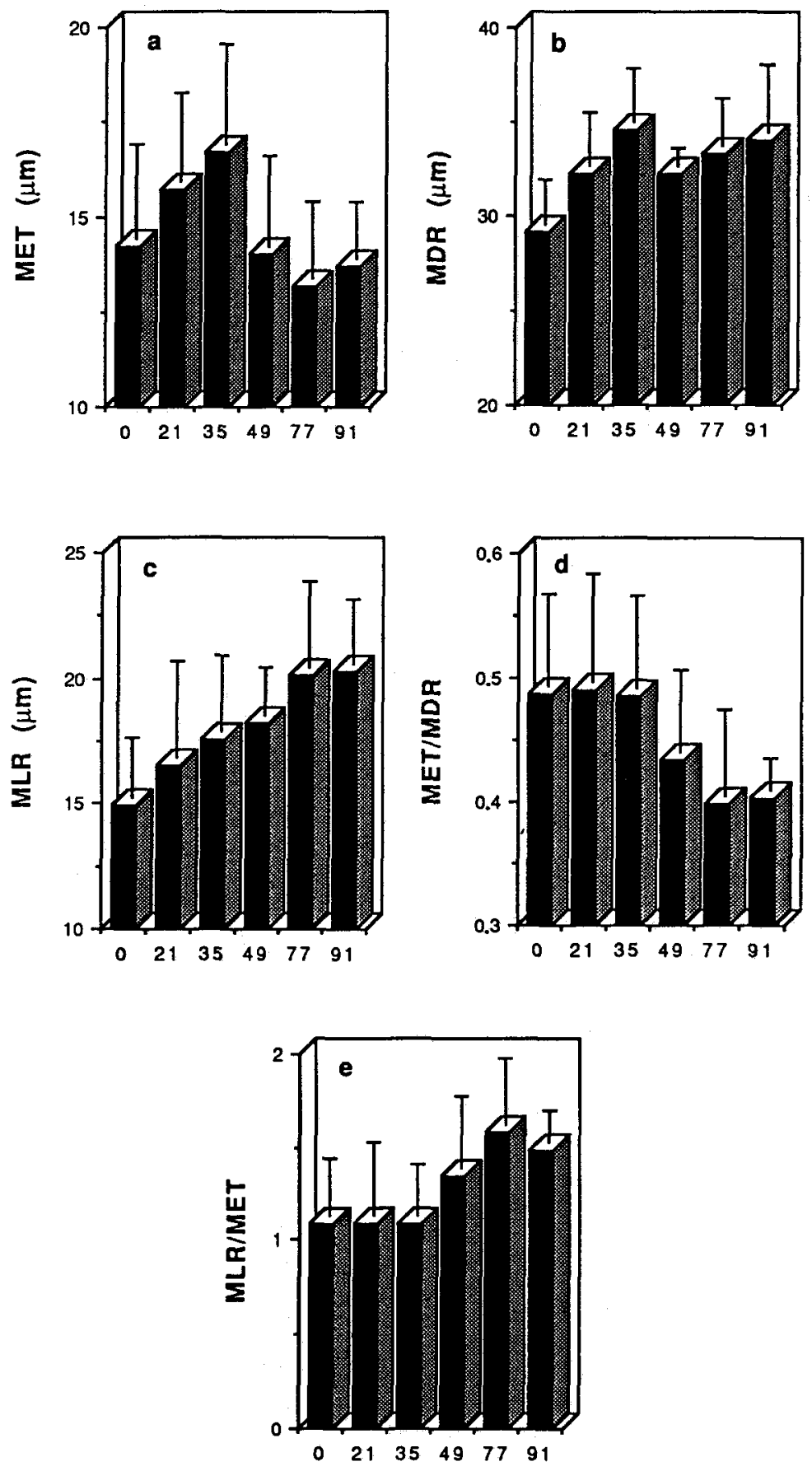

Fig. 3a-e. Results of the planimetric analysis of the digestive gland tubules. Vertical segments are $95 \%$ confidence intervals. a: MET; b: MDR; $\mathrm{c}$ :MLR; d: MET/MDR; e: MLR/MET 

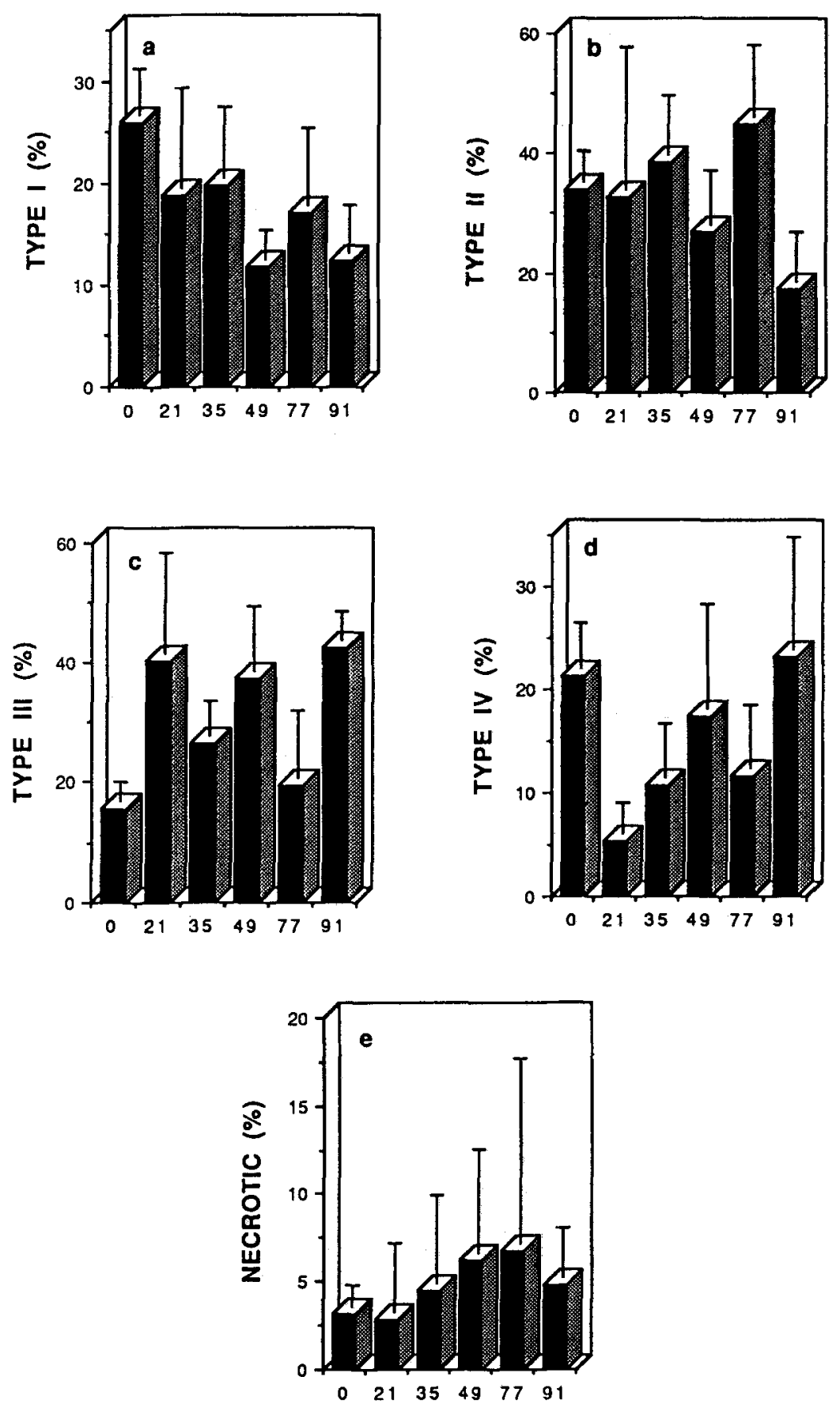

Fig. $4 a-e$. Results of the subjective tubule grading analysis of the digestive gland tubules. Vertical segments are $95 \%$ confidence intervals. a: Type I tubules; b: Type II tubules; c: Type III tubules; d: type IV tubules; e: necrotic tubules 
Table 2. One-way ANOVA to test significant differences between sampling periods. $F$ : $F$ ratio; $P(F)$ : probability of $F_{i}$ DFB: degrees of freedom between groups; DFW: degrees of freedom within groups

\begin{tabular}{|c|c|c|c|c|}
\hline Parameter & $\mathrm{F}$ & $P(F)$ & DFB & DFW \\
\hline MET & 2.7457 & $0.0322^{*}$ & 5 & 39 \\
\hline MDR & 4.7814 & $0.0017^{* *}$ & 5 & 39 \\
\hline MLR & 3.9419 & $0.0055^{* *}$ & 5 & 39 \\
\hline MET/MDR & 2.9003 & $0.0255^{*}$ & 5 & 39 \\
\hline MLR/MET & 3.2114 & $0.0160^{*}$ & 5 & 39 \\
\hline Type I \% & 1.8624 & 0.1233 & 5 & 39 \\
\hline Type II \% & 5.7987 & $0.0004^{* *}$ & 5 & 39 \\
\hline Type III \% & 6.5740 & $0.0002 * *$ & 5 & 39 \\
\hline Type IV \% & 2.6187 & $0.0391 *$ & 5 & 39 \\
\hline Necrotic $\%$ & 0.7193 & 0.6129 & 5 & 39 \\
\hline Bas VD & 8.1693 & $<0.00005^{* *}$ & 5 & 39 \\
\hline${ }^{*} \mathrm{P}<0.05_{i}{ }^{* *} \mathrm{P}<0.01$ & & & & \\
\hline
\end{tabular}

similar to the VD of mussels sampled on day 35 in comparison to the VD of mussels sampled on any other day. The ANOVA indicates that changes in this parameter are highly significant (Table 2).

Correlation and linear and logarithmic regression analyses were performed among planimetric parameters, percentages of tubule types and the VD of basophilic cells. Significant relationships between pairs of parameters, are given in Table 3 . The results

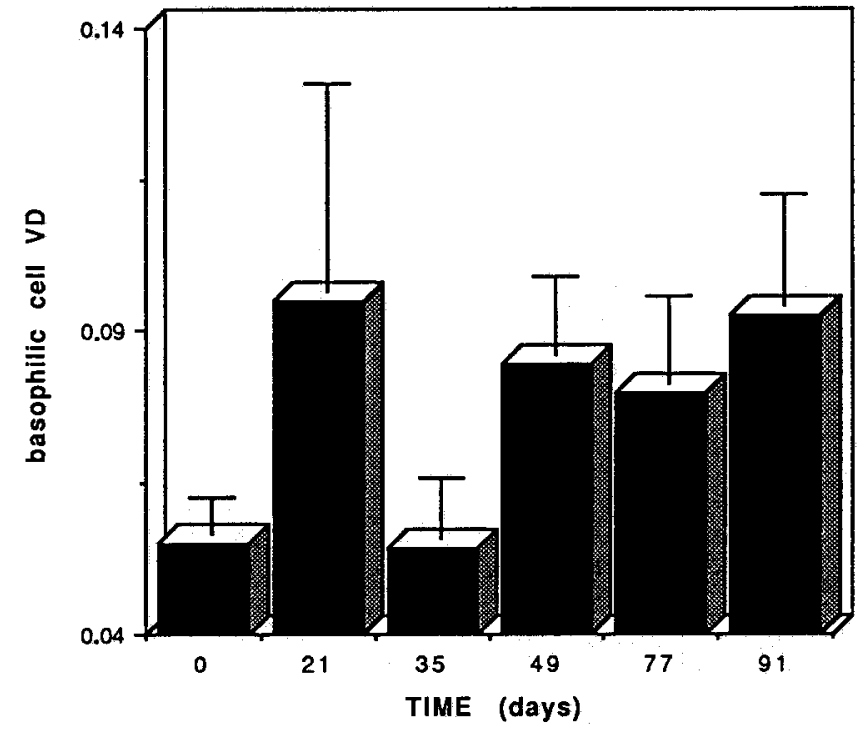

Fig. 5. Results of the stereological analysis of the basophilic cells of the digestive gland tubules. Vertical segments are $95 \%$ confidence intervals. VD $=$ volume density $\left(\mu \mathrm{m}^{3} / \mu \mathrm{m}^{3}\right)$ 


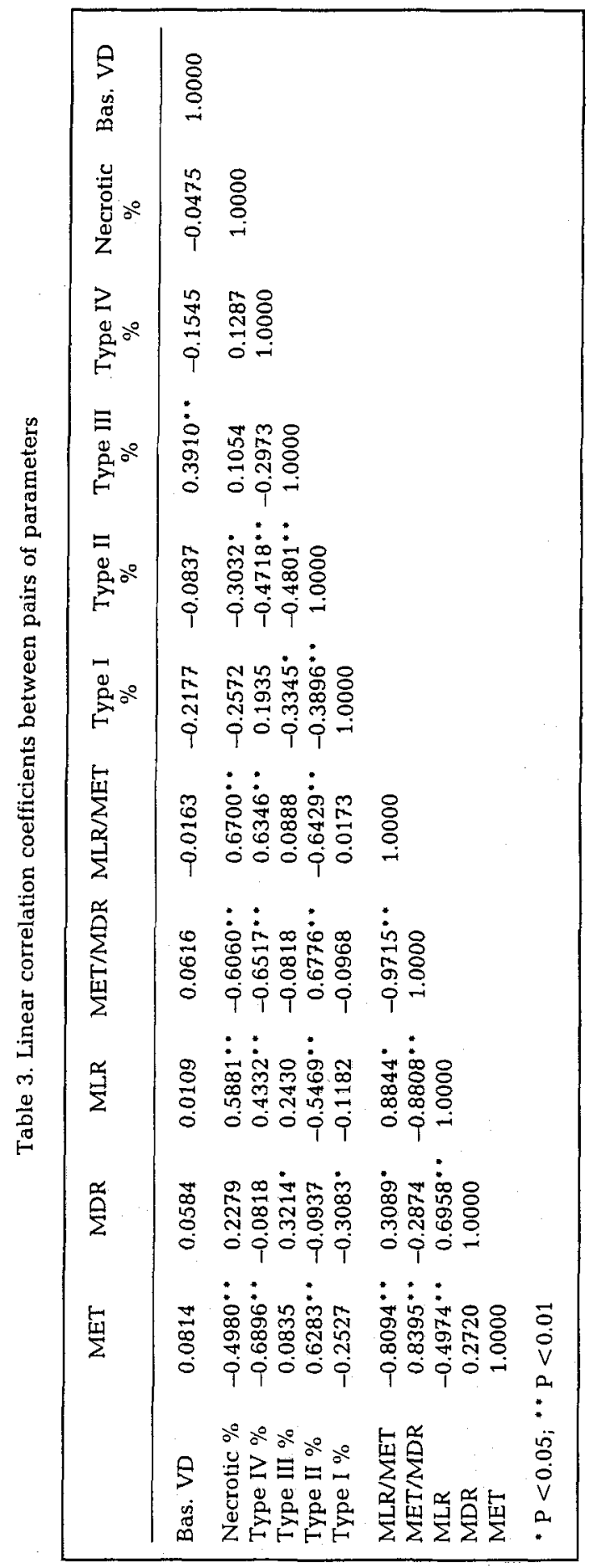


demonstrate that changes in the planimetric parameters (except MDR) were correlated with changes in the percentages of type II, type IV and necrotic tubules. As might be expected, higher digestive epithelial thickness (MET) values and MET/MDR values coincided with higher percentages of type II tubules and lower percentages of type IV and necrotic tubules. In contrast, the size of the digestive tubule lumen (MLR) and the ratio MLR/MET were negatively correlated with percentages of type II tubules and positively with percentages of type IV and necrotic tubules. Changes in the percentages of tubules in stages I and III were significantly correlated with the size of digestive tubules (MDR), type I tubules being relatively small and type III tubules relatively large (Fig. 1d). Finally, the VD of basophilic cells increased with increasing percentages of type III tubules, and the correlations of basophilic cell VD with any other parameter were not significant.

The ultrastructure of cells forming the digestive tubules of animals maintained for three months in the laboratory was found to be similar to that described in $M$. edulis (Thompson et al., 1974) and in other bivalve molluscs (Owen, 1970, 1972, 1973). The pyramid-shaped basophilic cells showed a well-developed rough endoplasmic reticulum in the basal and perinuclear portion, and typical secretory vesicles in the apical and mid portion (Fig. 6a). Prominent Golgi bodies were also found supranuclearly (Fig. 6a). Prominent Golgi bodies were also found supranuclearly (Fig. 6a). The apical part of the columnar digestive cells was filled with numerous small spherical and tubular vesicles (Fig. 6b) and with irregularly shaped heterophagosomes (Fig. 6a). Large heterolysosomes were found in the mid portion of the cells while residual bodies containing electron-dense material surrounded by a clear zone (Fig. 6a) were located mainly basally. Golgi bodies of classical appearance were also observed within the digestive cells (Fig. 6c). Tubules at different digestive stages showed different pinocytotic activity in the apex and different numbers of the lysosomal vesicles mentioned above. For instance, type IV tubules appeared to be for the most part inactive (Fig. 6d).

\section{DISCUSSION}

The morphology of the tubules in the digestive gland of experimental animals was not typical, compared to animals from the natural environment, which are subjected to a tidal regime. Langton (1975) reports that the percentage of type III plus IV tubules made up only $10 \%$ of the tubules in a mid-tidal mussel population. Under our experimental conditions, type II and III tubules were predominant throughout the assay, their relative importance varying from one sample to the other. Bright \& Ellis (1989) also report that absorptive and disintegrating tubules are predominant in an infaunal population of Macoma carlottensis. Type I and IV tubules also contribute significantly to the total tubule population of our experimental mussels.

Crystalline styles of varying sizes were present in mussels sampled at any time, including those starved for ten days. Robinson (1983) reports that quahogs, Mercenaria mercenaria, starved for 50 and 57 days had "high instances of missing crystalline styles". Langton (1977) shows that the style size decreases during the non-feeding period (exposure) in a mid-tidal mussel population but complete disappearance is not reported. In agreement with our results on mussels continually immersed, crystalline styles were rarely lacking in a subtidal population of $M$. mercenaria (Robinson \& Langton, 1980). 

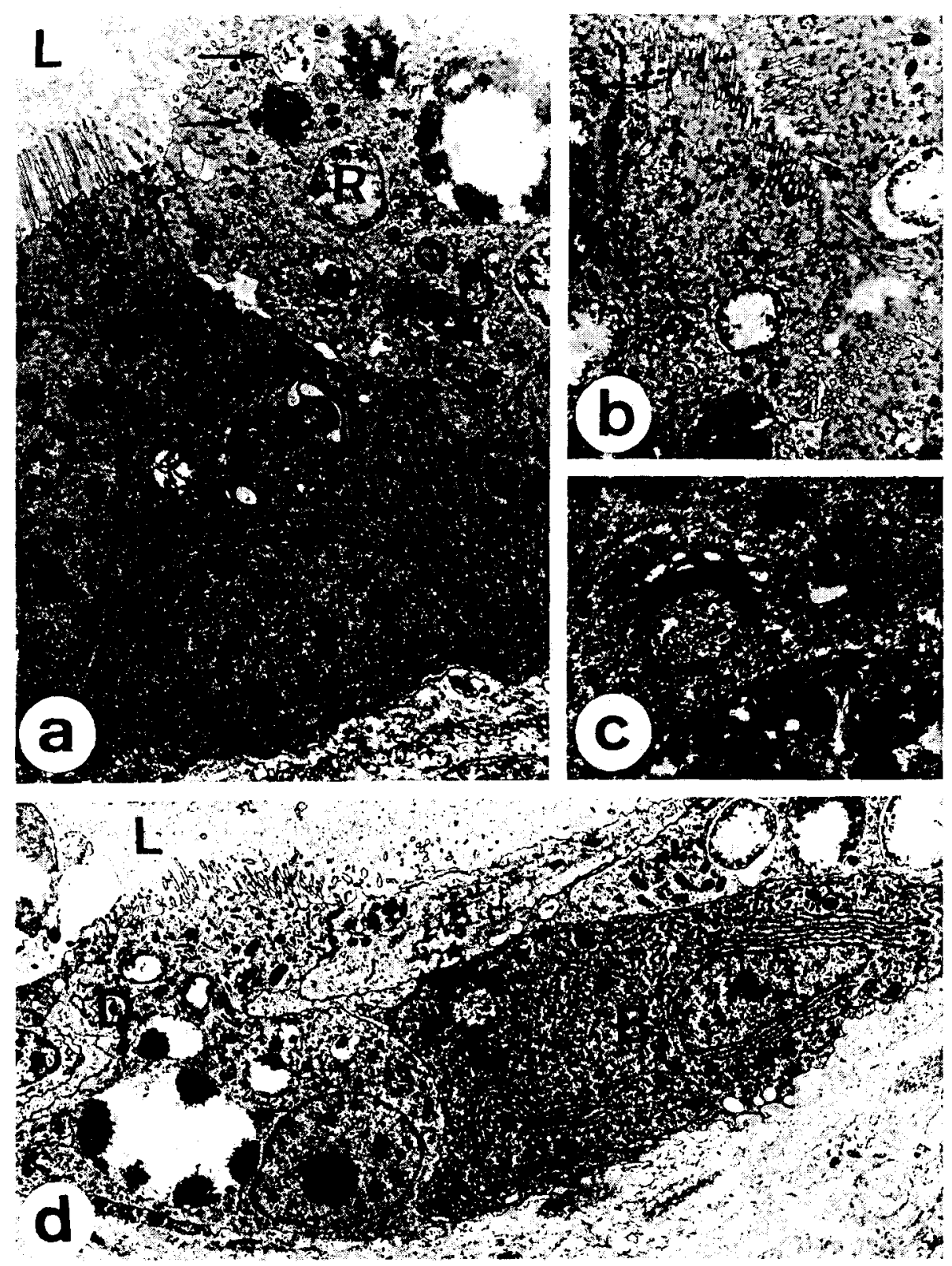

Fig. 6a-d. Mytilus galloprovincialis. Electron microscopy. Cross-sections through the digestive gland of mussels sampled after 91 days. a: Basophilic cell (B) showing a well-developed rough endoplasmic reticulum, an active Golgi body (asterisk) and secretory vesicles. The digestive cell (D) shows numerous small vesicles, phagosomes (arrows) and residual bodies $(R) ; L$, tubule lumen. $\times 6500$. b: Note an intense pinocytotic activity (arrows) in the apex of digestive cells; $\times 5000$. c: Active Golgi body of a digestive cell. $\mathrm{R}=$ residual body; $\times 24000$. $\mathrm{d}$ : Detail of basophilic $(\mathrm{B})$ and digestive cells (D) in a type IV tubule. $\mathrm{L}=$ tubule lumen; $\times 4500$ 
Therefore, it can be suggested that the presence of the crystalline style is not correlated with the presence/absence of food material (the majority of the 10-day starved mussels shows well-formed styles) but with the conditions of immersion/exposure. It is also possible that a 10-day starvation period is not long enough to produce the disappearance of the style.

Both the 10-day starvation period and the long-term laboratory maintenance cause changes in the percentages of tubule types and in the planimetric parameters, indicating a general adaptation of mussels to changes in environmental conditions. The responses evoked by these two sources of stress will be considered separately.

When the five planimetric parameters are considered together, it becomes evident that experimental animals form two separate groups. Mussels sampled after 0, 21 and 35 days show higher values of MET, MDR and MET/MDR and lower values of MLR/MET than mussels sampled after 49,77 and 91 days. The lumen of the digestive tubules, measured as MLR, increases gradually over the experimental period and is clearly associated with increasing percentages of tubules in the reconstituting stage (type IV). Type II and III tubules show no particular time-dependent trend, but values of type III tubules are relatively high after 91 days maintenance in the laboratory. Several studies have suggested that the incidence of digestive tubules with dilated lumen increases when molluscs are subjected to different stress conditions (Thompson et al., 1974; Thompson et al., 1978; Couch, 1984). Some authors (Couch, 1984; Fournie et al., 1988) refer to this syndrome as "atrophy" of bivalve digestive tubule epithelia. The phenomenon has been further quantified as a reduction in the mean epithelial thickness (MET) of the digestive epithelium (Marigómez et al., 1986; Recio et al., 1988; Vega et al., 1989; Agirregoikoa et al., 1991) or as a reduction in other equivalent parameters indicative of digestive cell size (Lowe et al., 1981; Robinson, 1983; Axiak et al., 1988). Thus, swelling of the digestive tubule lumen and reduction of digestive epithelial thickness reflect a stress response in different species of molluscs, from the terrestrial gastropod Arion ater to the marine gastropod Littorina littorea and the marine bivalve Mytilus galloprovincialis. The results of this work also indicate that mussels kept for more than 35 days under the described laboratory conditions are not healthy. Nevertheless, the condition of mussels kept for more than 35 days was not as bad as the condition of mussels experimentally contaminated with petroleum hydrocarbons (Cajaraville et al., 1989), based on the measurement of the same parameters. Laboratory maintenance conditions may impose a temperature and nutritive stress on the animals, thus reducing their fitness. However, mussels are able to compensate changes in environmental conditions to some extent, and a new steady-state may then be reached. Bayne (1973) reports that the oxygen consumption rate declines to steady-state values after 22-30 days of laboratory maintenance, starting in late April, at $15^{\circ} \mathrm{C}$ and with an adequate food ration. In our experiment, carried out during April-June, the first sample was taken after 21 days and mussels from this sample were considered to be "healthy" or at least fully acclimated to laboratory conditions. In fact, the values of the planimetric parameters obtained for this sample are comparable with the values obtained in mussels sampled from the field at the same locality in the same period of the year (Pérez, 1989). The question is whether the stress response evoked after 35-49 days of experiment is caused directly by the long-term maintenance or indirectly by malnutrition, temperature stress and/or individual weakening associated with the reproductive condition. Starvation symptoms described in crusta- 
cean R-cells include a decreased cell volume, the reduction of the microvillous processes, small amounts of RER and mitochondria which become swollen, reduction or lack of Golgi fields, increased numbers of autolysosomes and residual bodies, depletion of reserve material and severe alterations of the basal lamina (Storch et al., 1982; Storch \& Burkhardt, 1984; Anger et al., 1985; Vogt et al., 1986). Very similar ultrastructural alterations have been recorded in the hepatocytes (Avila, 1986) and intestinal epithelial cells (Segner et al., 1987) of various teleosts upon starvation. In the digestive gland of $M$. edulis, the cytoplasm of the digestive cells is reduced in volume and density after a 4week starvation period, and disruption of digestive cell structure, which shows a cytoplasm deficient in inclusions, occurs after eleven weeks of starvation (Thompson et al., 1974). Basophilic cells degenerate earlier than digestive cells: disorganization of endoplasmic reticulum and inactive Golgi bodies are detected both after 4 weeks starvation and after 11 weeks feeding in the laboratory (Thompson et al., 1974). None of the alterations described above for starved animals were observed in our experimental mussels after the 3-month maintenance period. Golgi bodies were found to be especially well-developed in both digestive and basophilic cells, and changes in mitochondrial morphology, which are considered to be a specific response to starvation (Avila, 1986), were never observed. Digestive cells showed normal pinocytotic activity, and all the different components of the lysosomal system, including phagosomes (Owen, 1970, 1973), were present. The flagellated type II basophilic cell found to be prominent under laboratory conditions by Thompson et al. (1974) was not observed, or was not distinguished from normal basophilic cells, under the present experimental conditions. Signs of cellular degeneration, starting with the dilation of intercellular spaces, were always found associated with necrotic tubules which constituted a constant proportion $(5-10 \%)$ of the total tubule population at every sampling period. Ultrastructural alterations caused by the ingestion of inappropriate food (Storch \& Burkhardt, 1984; Avila, 1986; Vogt et al., 1986; Segner et al., 1987) were never observed and thus we conclude that the food used and the nutrition-related health status of the animals were adequate. Nevertheless, it seems that the dissolved organic matter present in the food is the nutritious component for mussels, since the particulate matter concentration (average particle diameter $5.25 \mu \mathrm{m}$ as measured with a Coulter-Counter) decreases very rapidly $(<1 \mathrm{~h}$ ) to very low levels when filter-feeder organisms are present (Dr. E. Navarro, pers. comm.). Some naturally occurring particulate material (bacteria?) may also have been used for food by mussels.

A temperature stress may have existed throughout the assay; but, as temperature was maintained nearly constant during the assay and no significant increases were recorded around the critical days 35-49, temperature itself is not enough to explain the stress response recorded in animals from the 35-day sample on. Most probably, changes in mussel reproductive condition were the cause of the stress response recorded. The seasonal reproductive cycle profoundly affects the biochemical, cellular and physiological processes in mussels and, as shown by Bayne et al. (1978), increased stress is evident following spawning. Mussel digestive cells show disruption of structure and evidence of autolysis (i.e. lysosomal destabilization) after spawning (Bayne et al., 1978). The process of digestive cell autolysis may lead to a reduction in digestive cell volume, which may in turn be reflected in changes in both planimetric parameters and tubule type proportions, as observed after the 35-day maintenance period. In fact, the GI shows a great reduction 
at day 35 in females, and the first completely spent males appear also at this sampling period.

Mussels starved for 10 days show a number of features that differentiate them from animals of further samplings: MET values of starved mussels are lower than those of mussels fed for 21 and 35 days. MDR values are also lower and, as indicated by the correlation analysis, could be related to the high percentage of type I tubules in this experimental group. Since decreases in these two parameters are of the same magnitude, no changes in MET/MDR values are detected between groups of mussels sampled after 0,21 and 35 days. MLR values are low in the starved group but comparable to MLR values of mussels sampled after 21 and 35 days. This result, together with results concerning the parameter MET, clearly indicate that although a stress response is caused by the 10-day starvation period, the stress response evoked by the long-term laboratory maintenance is of higher magnitude and significance.

Concerning the morphology of digestive tubules, the percentages of type I and IV tubules are particularly high, while the percentage of type III tubules is low in the animals starved for 10-days. The work of Lowe (1988) implies, on the basis of non-quantitative data, that food deprivation leads to a higher incidence of tubules in resting (type I) condition, while chemical pollution is characterized by an increase in tubules with a very thin digestive epithelium (type IV). The fact that type I tubules increase (and type II tubules subsequently decrease) in starved mussels has long ago been demonstrated (Langton, 1975) and is confirmed by the present study. Apart from a high proportion of type I tubules, 10-day starved animals also show a high percentage of type IV tubules in the present experimental conditions, contrary to the results reported by Langton (1975) and Robinson (1983). However, our results agree with those of Thompson et al. (1978) and Thompson et al. (1974) in which starvation periods of 13 days and 4 weeks, respectively, cause increased proportions of type IV tubules in mussels, as derived from their published photomicrographs. Winstead \& Couch (1988) also report that oysters, Crassostrea virginica, held without food for several weeks show diminished digestive tubule epithelia. These results indicate that a higher incidence of type IV tubules is not only indicative of pollution-induced pathology, as suggested by Lowe (1988), but is a rather general and unspecific adaptive response of mussels to inappropriate maintenance conditions. The present study also shows that mussels can easily recover from the starved condition since MET, MLR and MET/MDR values increase, and percentages of type I and IV tubules decrease after 21 days of normal food supply.

With regard to the percentage of necrotic tubules, there is no significant alteration in this parameter over the experimental period. The investigations of Agirregoikoa (1988) and Pérez (1989) on mussels collected from the same area also indicate a conspicuous incidence $(0-13 \%)$ of necrotic tubules in most periods of the year. Recent studies have suggested a relationship between the occurrence of necrotic tubules in bivalves and different stress conditions such as pollution (Berthou et al., 1987; Auffret, 1988; Gardner \& Yevich, 1988; Bright \& Ellis, 1989), temperature stress (Henry, 1987) and malnutrition (Henry, 1987; Catacutan \& De la Cruz, 1989). However, Cajaraville et al. (1989) found no significant increases in the percentage of necrotic tubules in mussels experimentally treated with petroleum hydrocarbons. Further studies are being conducted in our laboratory to elucidate the causative agents of digestive tubule necrosis in mussels from the Basque Coast. 
Various studies have evaluated the intracellular digestive process as reflected by changing morphology of the digestive gland tubules (Langton, 1975; Robinson \& Langton, 1980). Robinson \& Langton (1980) further demonstrate that the tubule grading procedure is consistent and reproducible. However, in our opinion this technique implies great subjectivity (which gives rise to high variability when compared with objectively measured planimetric parameters) and the gradation needs to be performed by experienced researchers. In any case, type IV tubules are the most easily identified tubules, and the measurement of their incidence could thus be used as a rapid and cheap screening test to evaluate the overall condition of mussels. Besides, type IV tubules have a physiological relevance, as type IV tubule abundance displays a temporally lagged correlation with the rates of faecal deposition (Hawkins et al., 1983). However, both studies concerning the assessment of environmental pollution effects and studies on intracellular digestion will undoubtedly require the use of quantitative methods such as stereology (Lowe et al., 1981; Robinson, 1983), direct measurement technics (Robinson, 1983; Axiak et al., 1988) or planimetry (Marigómez et al., 1986; Recio et al., 1988; Vega et al., 1989). The latter method has the advantage of giving information not only on digestive cell height, but also on other parameters subject to changes according to environmental conditions, i.e. tubule size (Morton, 1983; Robinson, 1983) and tubule lumen size (Langton, 1975; Couch, 1984; Vega et al., 1989). Furthermore, as pointed out by Vega et al. (1989), the use of combined parameters such as MET/MDR and MLR/MET could indicate relative changes between luminal size, digestive cell volume and tubule size, thus integrating the factors influencing the variability in digestive gland tubule morphology. In addition, these planimetric parameters are well-correlated with indices of the same level of biological organisation (i.e. changes in lysosomal system structure; Marigómez et al., 1989) and with indices of higher levels of biological organisation (i.e. flesh condition index; Agirregoikoa et al., 1991). The sensitivity of the five planimetric parameters used has been proven in the present work; alterations indicating a stress condition being demonstrated earlier and more significantly than when subjective tubule morphology changes are considered. Finally, the present work demonstrates for the first time the correlation between subjective digestive tubule morphology and quantitative parameters that measure changes in digestive epithelium thickness, digestive tubule size, and digestive tubule lumen size. Of particular interest is that some types of digestive tubules (I and III) show predictable tubule size, while type II and IV tubules are variable in size. Robinson (1983) also reports that there is no significant relationship between tubule width and the proportion of type II tubules. A second important contribution of this work is to show that different tubular types bear different numbers of basophilic cells. Particularly the percentage of type III tubules is positively correlated with the VD of basophilic cells, which strengthens the hypothesis of an active participation of bivalve basophilic cells in both the digestion process and the turnover of digestive cells (Cajaraville et al., 1990a).

Acknowledgements. This investigation forms part of the Research Project X-86.041 funded by the Basque Government. The study was also partially financed by the Basque Government through a fellowship to M. P. Cajaraville. The authors are especially grateful to C. Otamendi for her excellent technical assistance in the preparation of specimens for electron microscopy and to the staff of the Department of Neurosciences (UPV-EHU) for use of the electron microscope facilities. We are also indebted to P. Larrea and to many other students at our laboratory for their skilful technical support. 


\section{LITERATURE CITED}

Agirregoikoa, M. G., 1988. Mytilus edulis bibalbioaren liseri-epitelioaren batezbesteko lodieraren aldakuntz espazio-tenporala Bizkaiko kostaldean. Licenciature Thesis, Univ. of the Basque Country, Bilbao, $71 \mathrm{pp}$.

Agirregoikoa, M. G., Pérez, M. A., Marigómez, J. A. \& Angulo, E., 1991. Relationship between quantitative indices of individual and digestive cell conditions in the common mussel, Mytilus edulis L., from the Biscay Coast. - Acta Hydrochim. Hydrobiol. 19, 29-37.

Anger, K., Storch, V., Anger, V. \& Capuzzo, J. M., 1985. Effects of starvation on moult cycle and hepatopancreas of Stage I lobster Homarus americanus larvae. - Helgoländer Meeresunters. 39 , $107-116$.

Auffret, M., 1988. Histopathological changes related to chemical contamination in Mytilus edulis from field and experimental conditions. - Mar. Ecol. Prog. Ser. 46, 101-107.

Avila, E. M., 1986. Evaluation of practical diets in the culture of the rabbitfish, Siganus guttatus (Bloch) (Pisces: Siganidae) using liver ultrastructural methods. - Zool. Anz. 217, 178-191.

Axiak, V., George, J. J. \& Moore, M. N., 1988. Petroleum hydrocarbons in the marine bivalve Venus verrucosa: accumulation and cellular responses. - Mar. Biol. 97, 225-230.

Bayne, B. L., 1973. Physiological changes in Mytilus edulis L. induced by temperature and nutritive stress. - J. mar. biol. Ass. U.K. 53, 39-58.

Bayne, B. L. \& Thompson, R. J., 1970. Some physiological consequences of keeping Mytilus edulis in the laboratory. - Helgoländer Meeresunters. 20, 526-552.

Bayne, B. L., Holland, D. L., Moore, M. N., Lowe, D. M. \& Widdows, J., 1978. Further studies on the effects of stress in the adult on the eggs of Mytilus edulis. - J. mar. biol. Ass. U.K. 58, 825-841.

Berthou, F., Balquet, G., Bodennec, G. \& Marchand, M., 1987. The occurrence of hydrocarbons and histopathological abnormalities in oysters from seven years following the wreck of the Amoco Cadiz in Brittany (France). - Mar. environ. Res. 23, 103-133.

Bright, D. A. \& Ellis, D. E., 1989. Aspects of histology in Macoma carlottensis (Bivalvia: Tellinidae) and "in situ" histopathology related to mine-tailings discharge. - J. mar. biol. Ass. U.K. 69, $447-464$,

Cajaraville, M. P., Díez, G., Larrea, P., Marigómez, J. A. \& Angulo, E., 1989. Planimetric parameters of the digestive tubules of Mytilus edulis: Sensitive tools for monitoring petroleum hydrocarbon toxicity? - Abstr. int. Symp. Mussel, Galicia (Spain), 1-15.

Cajaraville, M. P., Díez, G., Marigómez, J. A. \& Angulo, E., 1990a. Responses of basophilic cells of the digestive gland of mussels to petroleum hydrocarbon exposure. - Dis. aquat. Org. 9, 221-228.

Cajaraville, M. P., Marigómez, J. A. \& Angulo, E., 1990b. Short-term toxic effects of 1-naphthol on the digestive gland-gonad complex of the marine prosobranch Littorina littorea (L.): a light microscopic study. - Archs environ. Contam. Toxicol. 19, 17-24.

Cajaraville, M. P., Marigómez, J. A. \& Angulo, E., 1990c. Ultrastructural study of the short-term toxic effects of naphthalene on the kidney of the marine prosobranch Littorina littorea. - J. Invertebr. Pathol. 55, 215-224.

Catacutan, M. R. \& De la Cruz, M., 1989. Growth and mid-gut cells profile of Penaeus monodon juveniles fed watersoluble-vitamin-deficient diets. - Aquaculture 81, 137-144.

Couch, J. A, 1984. Atrophy of diverticular epithelium as an indicator of environmental irritants in the oyster, Crassostrea virginica. - Mar, environ. Res. 14,525-526.

Fournie, J. W., Foss, S. S. \& Couch, J. A., 1988. A multispecies system for evaluation of infectivity and pathogenicity of microbial pest control agents in non-target aquatic species. - Dis. aquat. Org. 5 , $63-70$.

Gardner, G. R. \& Yevich, P. P., 1988. Comparative histopathological effects of chemically contaminated sediment on marine organisms. - Mar. environ. Res. 24, 311-316.

Goldberg, E. D., 1986. The mussel watch concept. - Environ. Monit. Assess. 7, 91-103.

Hawkins, A. J. S., Bayne, B. L. \& Clarke, K. R., 1983. Coordinated rhythms of digestion, absorption and excretion in Mytilus edulis (Bivalvia: Mollusca). - Mar. Biol. 74, 41-48.

Henry, M., 1987. Glande digestive de la palourde Ruditapes decussatus L. - Vie mar. (Hors sér.) 9, $1-439$.

Hummel, H., 1985. Food intake and growth in Macoma balthica (Mollusca) in the laboratory. - Neth. J. Sea Res. 19, 77-83. 
Langton, R. W., 1975. Synchrony in the digestive diverticula of Mytilus edulis L. - J. mar. biol. Ass. U.K. 55, 221-230.

Langton, R. W., 1977. Digestive rhythms in the mussel Mytilus edulis. - Mar. Biol. 41, 53-58.

Lanno, R. P., Hickie, B. E. \& Dixon, D. G., 1989. Feeding and nutritional considerations in aquatic toxicology. - Hydrobiologia 188-189, 525-531.

Livingstone, D. R., Moore, M. N. \& Widdows, J., 1988. Ecotoxicology: biological effects measurements on molluscs and their use in impact assessment. In: Pollution of the North Sea. Ed. by W. Salomons, E. K. Duursma, B. L. Bayne \& U. Förstner. Springer, Berlin, 624-637.

Lowe, D. M., 1988. Alterations in the cellular structure of Mytilus edulis resulting from exposure to environmental contaminants under field and experimental conditions. - Mar. Ecol. Prog. Ser. 46, 91-100.

Lowe, D. M., Moore, M. N. \& Clarke, K. R., 1981. Effects of oil on the digestive cells in mussels: quantitative alterations in cellular and lysosomal structure. - Aquat. Toxicol. 1, 213-226.

Marigómez, J. A., Angulo, E. \& Moya, J., 1986. Copper treatment of the digestive gland of the slug Arion ater L. 2. Morphometrics and histophysiology. - Bull. environ. Contam. Toxicol. 36, 608-615.

Marigómez, J. A., Vega, M. M., Cajaraville, M. P. \& Angulo, E., 1989. Quantitative responses of the digestive-lysosomal system of winkles to sublethal concentrations of cadmium. - Cell. mol. Biol. $35,555-562$.

Marigómez, J. A., Cajaraville, M. P. Angulo, E. \& Moya, $J_{*}, 1990$. Ultrastructural alterations in the renal epithelium of cadmium-treated Littorina littorea (L.). - Archs environ. Contam. Toxicol. 19, 863-871.

Marigómez, J. A., Cajaraville, M. P. \& Angulo, E., 1991. Effects of sublethal exposure to cadmium on the ultrastructure of the gills of the gastropod Littorina littorea. - Z. mikrosk. - anat. Forsch. (In press.)

Morton, B. S., 1983. Feeding and digestion in bivalves. In: The mollusca. Ed. by M. Wilburg \& A. S. M. Saleuddin. Acad. Press, New York, 5, 563-583.

Owen, G., 1970. The fine structure of the digestive tubules of the marine bivalve Cardium edule. Phil. Trans. R. Soc. Lond. 258, 245-260.

Owen, G., 1972. Lysosomes, peroxisomes and bivalves, - Sci. Prog., Oxford 60, 299-318.

Owen, G., 1973. The fine structure and histochemistry of the digestive diverticula of the protobranchiate bivalve Nucula sulcata. - Proc. R. Soc. Lond. 183, 249-264.

Papathanassiou, E. \& King, P. E., 1986. Ultrastructural changes in hepatopancreatic cells of the prawn Palaemon serratus induced by exposure to acutely toxic cadmium concentrations. - Dis. aquat. Org. 2, 39-47.

Pérez, M. A., 1989. Seguimiento del estrés ambiental después de un vertido de crudo: análisis histológico en Mytilus edulis (L.). Licenciature Thesis, Univ, of the Basque Country, Bilbao, 123 pp.

Recio, A., Marigómez, J. A., Angulo, E. \& Moya, J., 1988. Zinc treatment of the digestive gland of the slug Arion ater L. 2. Sublethal effects at the histological level. - Bull. environ. Contam. Toxicol. $41,865-871$.

Robinson, A. G. \& Dillaman, R. M., 1985. The effects of naphthalene on the ultrastructure of the hepatopancreas of the fiddler crab, Uca minax. - J. Invertebr. Pathol. 45, 311-323.

Robinson, W. E., 1983. Assessment of bivalve intracellular digestion based on direct measurements. - J. moll. Stud. 49, 1-8.

Robinson, W. E. \& Langton, R. W., 1980. Digestion in a subtidal population of Mercenaria mercenaria (Bilvalvia). - Mar. Biol. 58, 173-179.

Seed, R., 1969. The ecology of Mytilus edulis L. (Lamellibranchiata) on exposed rocky shores. Oecologia 3, 277-316.

Segner, H., Burkhardt, P., Avila, E. M., Juario, J. V. \& Storch, V., 1987. Nutrition-related histopathology of the intestine of milkfish Chanos chanos Fry. - Dis. aquat. Org. 2, 99-107.

Sindermann, C. J., 1988. Biological indicators and biological effects of estuarine/coastal pollution. Wat. Resour. Bull. 24, 931-939.

Sokal, R. R. \& Rohlf, F, J., 1979. Biometría. Blume, Madrid, 832 pp.

Storch, V. \& Burkhardt, P., 1984. Influence of nutritional stress on the hepatopancreas of Talitrus saltator (Pericarida, Amphipoda). - Helgoländer Meeresunters. 38, 65-73. 
Storch, V., Janssen, H. H. \& Cases, E., 1982. The effects of starvation on the hepatopancreas of the coconut crab, Birgus latro (L.) (Crustacea, Decapoda). - Zrorl. Anz. 208, 115-123.

Thompson, R. J., Ratcliffe, N. A. \& Bayne, B. L., 1974. Effects of starvation on structure and function in the digestive gland of the mussel Mytilus edulis L. - J. mar. biol. Ass. U. K. 54, 699-712.

Thompson, R. J., Bayne, C. J., Moore, M. N. \& Carefoot, T. J., 1978. Haemolymph volume, changes in the biochemical composition of the blood, and cytological responses of the digestive cells in Mytilus californianus Conrad induced by nutritional, thermal and exposure stress. - J. comp. Physiol. 127, 287-298.

Vega, M. M., Marigómez, J. A. \& Angulo, E., 1989. Quantitative alterations in the structure of the digestive cell of Littorina littorea on exposure to cadmium. - Mar. Biol. 103, 547-553.

Vogt, G., 1987. Monitoring of environmental pollutants such as pesticides in prawn aquaculture by histological diagnosis. - Aquaculture 67, 157-164.

Vogt, G., Quinitio, E. T. \& Pascual, F. P., 1986. Leucaena leucocephala leaves in formulated feed for Penaeus monodon: a concrete example of the application of histology in nutrition research. Aquaculture 59, 209-234.

Weibel, E. R., 1979. Stereological methods. Acad. Press, London, 1, 1-415.

Winstead, J. T. \& Couch, J. A., 1988. Enhancement of protozoan pathogen Perkinsus marinus infections in american oysters Crassostrea virginica exposed to the chemical carcinogen nnitrosodiethylamine (DENA). - Dis. aquat. Org. 5, 205-213. 